\title{
Effects of oocyte source, cell origin, and embryo reconstruction procedures on in vitro and in vivo embryo survival after goat cloning
}

\author{
Cristiano Feltrin ${ }^{1}$, Luís Henrique de Aguiar ${ }^{1}$, Carlos Enrique Méndez Calderón ${ }^{1}$, Igor de Sá Carneiro ${ }^{1}$, \\ Felipe de Jesus Moraes Junior ${ }^{1}$ Josiane da Silva Quetz $^{2}$, Aldo Ângelo Moreira Lima ${ }^{2}$, Matthew Wheeler ${ }^{3}$, \\ Davide Rondina ${ }^{4}$, José Luiz Rodrigues, James Donald Murray ${ }^{6}$, Elizabeth Anne Maga ${ }^{6}$, Luciana Relly \\ Bertolini $^{1,7}$, Marcelo Bertolini, ${ }^{1,5,8}$
}

\author{
${ }^{1}$ Molecular and Developmental Biology Laboratory, University of Fortaleza, Fortaleza, CE, Brazil. \\ ${ }^{2}$ Institute of Biomedicine for Brazilian Semi-Arid \& Clinical Research Unit, Federal University of Ceará, Fortaleza, CE, Brazil. \\ ${ }^{3}$ The Institute for Genomic Biology, Department of Animal Sciences, University of Illinois, Urbana-Champaign, IL, USA. \\ ${ }^{4}$ Laboratory of Ruminant Nutrition and Production, School of Veterinary Medicine, Ceará State University, Fortaleza, CE, Brazil. \\ ${ }^{5}$ Laboratory of Embryology and Biotechnology of Reproduction, Federal University of Rio Grande do Sul, Porto Alegre, RS, \\ Brazil. \\ ${ }^{6}$ Transgenics Laboratory, Department of Animal Science, University of California, Davis, CA, USA. \\ ${ }^{7}$ Biotechnology and Genetic Engineering Lab, School of Pharmacy, Pontifical Catholic University of Rio Grande do Sul, Porto \\ Alegre, RS, Brazil.
}

\begin{abstract}
The birth of cloned goats has been well documented, but the overall goat cloning efficiency by somatic cell nuclear transfer procedures is still low, which may be further intensified in extreme environments. The aim of this study was to produce cloned goats under the conditions of the Brazilian SemiArid region, in a transgenic program for the expression of human lysozyme in the milk to target childhood diarrhea and malnutrition, comparing the effects of oocyte source, cell type, and embryo reconstruction procedures on in vitro and in vivo embryo survival after cloning by micromanipulation or by handmade cloning. The use of in vitro-matured oocytes resulted in more viable embryos after cloning than in vivo-matured cytoplasts, but no differences in pregnancy rates on day 23 were seen between oocyte sources $(77.5$ vs. $77.8 \%$, respectively). The presence or absence of the zona pellucida for embryo reconstruction $(78.8 v s .76 .0 \%$, respectively) did not affect pregnancy outcome after transfer. However, pregnancy rate on day 23 was higher for embryos chemically activated by a conventional than a modified protocol (88.1 vs. $50.0 \%)$, and for embryos reconstructed with mesenchymal stem cells and fetal fibroblasts (100.0 and 93.3\%) than with adult fibroblasts $(64.7 \%)$. Although most pregnancies were lost, the birth of a cloned female was obtained from embryos reconstructed by micromanipulation using non-transgenic control cells and in vitro-matured oocytes with intact zona pellucida, after conventional activation and transfer at the 1-cell stage.
\end{abstract}

Keywords: goats, oocyte maturation, somatic cell nuclear transfer, zona-free embryos.

\section{Introduction}

Childhood diarrhea and malnutrition still are some of the major social problems in developing countries. This is especially true in less favorable regions such as the Semi-Arid area of Brazil, resulting in thousands of infant deaths worldwide each year (Boccolini et al., 2012). Several epidemiological studies have already demonstrated the benefits of breast feeding for the infant's health, including passive immunedefense against infections by pathogenic microorganisms, growth stimuli to benign agents in the intestinal microbiota, development and maturation of the gastrointestinal tract, protection against asthma and allergies, and anti-inflammatory effects (Lönnerdal, 2003; Oddy, 2017). The positive effects of human milk to breastfed children are reflected in an improved general health, adequate growth and development including epigenetic beneficial changes, lower susceptibility to chronic and acute diseases during and after childhood, (American Academy of Pediatrics, 1997, Verduci et al., 2014), and lower incidence of infections of the gastrointestinal, respiratory and urinary tracts (Levy, 1998). Recently, breastfeeding for at least 12 months also been shown to be associated with improvement in children neurodevelopment, an increase in IQ scores, more schooling and higher salaries as adults (Victora et al., 2015; Lechner and Vohr, 2017). Such effects on the health of the young have been attributed to the presence of immunocompounds in human breast milk, such as lysozyme, lactoferrin and secretory immunoglobulin A, or IgA (Levy, 1998; Hassiotou and Geddes, 2015). The antimicrobial effects of human lysozyme and lactoferrin are considered as integral part of the passive immunity and defense against bacteria, viruses, parasites and fungi that is passed on to children through human breast milk (Mountzouris et al., 2002; Chow et al., 2016; Lönnerdal, 2016). Unfortunately, breastfeeding and the supply of such compounds to the infant are not permanent, which normally causes an impact on the child's health in unassisted populations. In contrast, the milk produced by livestock, such as goats, can be easily and continuously obtained, and used as a substitute for the nutritional properties of breast milk. However, lysozyme and lactoferrin are present in insufficient 
concentrations in animal's milk to provide effective protection to humans (Stenfors et al., 2002; Krol et al., 2010). Therefore, the production of human immunocompounds in the milk of domestic animals through genetic engineering could contribute to human gastrointestinal health by modulating the resistance and susceptibility to various diseases, such as childhood diarrhea (Maga and Murray, 1995; Maga et al., 2006a, b). Because of this potential, the production of transgenic goats to express human lysozyme (hLZ) in the milk may have a great impact on society (Maga et al., 2006a, b; Cooper et al., 2015), especially for the population of less favorable areas in the world, such as the Brazilian Semi-Arid region. For such purposes, cloning by somatic cell nuclear transfer (SCNT) may be useful for the production of goats for the lysozyme and lactoferrin transgenic models (Meng et al., 2012).

Goat cloning by SCNT has been established since late 1990s (Baguisi et al., 1999), but the successful application of the technology is still challenging, which is translated by the low overall efficiency $(<1$ to $5 \%$ ) of the process as a whole (Baldassare et al., 2004; Gavin et al., 2013) in more favorable regions of the world. Technical and biological aspects associated with such low efficiency are further intensified when facing climatically extreme and more challenging environments, such as the Brazilian SemiArid region. Even though goats are generally considered more adaptable to adverse conditions than other domestic animals, high temperatures and low rainfall also affect this species through the lack of good quality food, excessive temperatures, and the presence of toxic plants, among other factors to which the animals are constantly exposed to (Carneiro, 2008; Chaves et al., 2011). As a consequence, an overall decrease in reproductive efficiency may occur (Chaves et al., 2010, 2011), which can make the production of a cloned animal even more challenging. The adjustment of SCNT cloning procedures in goats, therefore, gains crucial importance in this specific environment, given that no reports of cloned goats produced in Brazil and between parallels $30^{\circ} \mathrm{N}$ and $30^{\circ} \mathrm{S}$ in the world have been available prior to this study and to our previous recent report (Martins et al., 2016).

The aim of this study was to optimize goat cloning procedures under the conditions of the Brazilian Semi-Arid region, using somatic donor cells transgenic for the hLZ gene, through experiments evaluating the in vitro and in vivo survival of goat embryos cloned by micromanipulation or Handmade Cloning (HMC), comparing different cytoplast sources (in vivo- or in vitro-matured oocytes), karyoplast types (adult fibroblasts, fetal fibroblasts and mesenchymal stem cells), and manipulation and reconstruction procedures for the production of goat cloned embryos.

\section{Materials and Methods}

All reagents and the water used for medium preparation were from Sigma Chemical Co. (St Louis, MO, USA), unless stated otherwise.
Cytoplast source: in vitro-matured and in vivo-matured oocytes

Two cytoplast (oocytes) sources were compared for the production of cloned goat embryos, either by micromanipulation or by HMC procedures, as below.

\section{In vitro maturation}

Goat ovaries were obtained post-mortem from pubertal adult goats and transported in DPBS (Nutricell, São Paulo, Brazil) to the laboratory in an insulated container at $33^{\circ} \mathrm{C}$. Cumulus-oocyte complexes (COCs) were obtained by ovary slicing. Viable COCs, selected based on morphological quality adapted from Leibfried and First (1979), were in vitro-matured (IVM) for $22 \pm$ $2 \mathrm{~h}$, according to Pereira et al. (2013).

\section{In vivo maturation.}

Healthy pubertal adult goats were subjected to ovarian stimulation for the collection of in vivo-matured oocytes. For that, an intravaginal progesterone insert (Eazi-Breed CIDR ${ }^{\circledR}$, Laboratórios Pfizer Ltda., Brazil) was placed on day 0 , with the replacement by a new one after 6 days. On day 10, a total of $180 \mathrm{mg} \mathrm{pFSH}$ (Folltropin- ${ }^{\circledR}$, Bioniche, USA) was given IM, twice a day, for 3 days (36 and 36, 36 and 36, 18 and $18 \mathrm{mg}$, respectively). The progesterone insert was removed at the last FSH dose (day 12), and approximately $15 \mathrm{~h}$ after removal, a dose of $0.025 \mathrm{mg}$ of gonadorelin acetate $\left(\right.$ Gestran $^{\circledR}$, ARSA S.R.L., Argentina), an analogue of GnRH, was given IM. Twenty-two hours $(22 \mathrm{~h})$ following the $\mathrm{GnRH}$ dose, ovaries were exteriorized by laparoscopy for the aspiration of $>4 \mathrm{~mm}$ follicles with a $10 \mathrm{ml}$ syringe attached to an $18 \mathrm{G}$ needle. Recovered oocytes were selected according to the expansion of the cumulus cells and the presence of the first polar body (PB) under a stereomicroscope.

For both oocyte sources, after the removal of the cumulus cells and selection of matured oocytes (PB selection), a group of oocytes from each source was subjected to enzymatic zona pellucida (ZP) removal in $0.5 \%$ protease (P8811) solution, according to Ribeiro et al. (2009) and Pereira et al. (2013), for subsequent embryo reconstruction by micromanipulation without ZP or by Handmade Cloning (HMC), as described below. The other group of oocytes from each source was kept with intact ZP for cloning by micromanipulation with $\mathrm{ZP}$.

Somatic cell nucleus donors for cloning, and cell cycle analysis

\section{Type of karyoplasts}

The somatic cells (karyoplasts) used for cloning were isolated from goats from the University of California, Davis, USA (CTNBio/Brazil 3467/2012), from a human lysozyme (hLZ) transgenic line. Mesenchymal stem cells (MSCs), adult fibroblast cells 
(AF), and fetal fibroblast cells (FF) were used for cloning by micromanipulation, whereas only MSCs and AF were used for Handmade Cloning, as below. Briefly, MSCs were isolated from the bone marrow of a neonate male; FF from a 40-day male fetus; and AF were obtained after the ear biopsy of a pubertal adult female, according to Baguisi et al. (1999), Monaco et al. (2009) and Gerger et al. (2010), respectively. The MSCs were used at $60-70 \%$ confluence (passage 4 ), the FF at 80 $90 \%$ confluence (passage 4 ), and the AF (passage 3 ) at $>95 \%$ confluence. Except for MSCs, the FF and AF cell cycles were synchronized by contact inhibition (high confluence) after 3 to 5 days of in vitro culture.

In a few cloning procedures $(n=3)$, fetal fibroblast cells obtained from a 40-day non-transgenic female fetus were used at low passage (P2) and high confluence $(>95 \%)$ as controls for cloning procedures and to evaluate in vitro and in vivo embryo survival. Due to the low frequency of use of such cells for cloning, data after the use of control cells are not presented in comparative form with the other transgenic $\mathrm{hLZ}$ cells lineages.

\section{Analysis of the cell cycle}

A portion of the MSCs, AF, and FF cells was used for cloning by micromanipulation, while the remaining cells were processed for the determination of the cell cycle phase through flow cytometry. Cultures of MSC, FF and AF cells were isolated with $0.25 \%$ trypsin-EDTA and centrifuged twice in DPBS. Then, cell were treated with $10 \mathrm{mg} / \mathrm{ml}$ RNase A (R4875) and $100 \mu \mathrm{g} / \mathrm{ml}$ propidium iodide (PI, P4170) in a $2.94 \%$ sodium citrate solution and $0.1 \%$ Triton $^{\mathrm{TM}} \mathrm{X}-100$ (T8787), for $30 \mathrm{~min}$ at RT. Cells were then centrifuged at $1500 \mathrm{~g}$ for $5 \mathrm{~min}$, at $4^{\circ} \mathrm{C}$, re-suspended in DPBS and immediately placed in a container with ice for the determination of the cell cycle phase $(\mathrm{G} 0 / \mathrm{G} 1, \mathrm{~S}, \mathrm{G} 2 / \mathrm{M})$ by flow cytometry (FACSCalibur, Becton Dickinson, San Jose, CA, USA). Histogram plots were created using the Cell Quest software (Becton Dickinson). Percentage of cells within the various phases of the cell cycle were calculated using Cell Quest by gating $\mathrm{G} 0 / \mathrm{G} 1, \mathrm{~S}$, and $\mathrm{G} 2 / \mathrm{M}$ cell populations, with a scatterplot of red fluorescence (FL2-A x FL2-W).

Experiment 1: Production of goat cloned embryos by micromanipulation: effects of the enucleation of in vitro- or in vivo-matured oocytes with or without the zona pellucida, reconstruction with distinct karyoplast types by membrane fusion or cellular micro-injection, and embryo activation with or without cytochalasin B

\section{Enucleation with or without ZP}

Groups of zona-intact (ZI) and zona-free (ZF) in vitro- or in vivo-matured oocytes were enucleated by micromanipulation. For that, oocytes were first incubated for $15 \mathrm{~min}$ in TCM-HEPES supplemented with $5 \mu \mathrm{g} / \mathrm{ml}$ cytochalasin B (C6762) and $5 \mu \mathrm{g} / \mathrm{ml}$ Hoechst 33342 (B2883). For ZI oocytes, conventional micromanipulation procedures were performed, according to Baguisi et al. (1999) and Keefer et al. (2001). For ZF oocytes, enucleation by micromanipulation was performed according to Oback et al. (2003).

\section{Reconstruction by cell fusion (CF) or by donor cell microinjection (CI)}

For the reconstruction of ZI embryos, the nucleus donor cells (MSC, AF or FF) were either transferred by micromanipulation to the perivitelline space of enucleated goat oocytes (reconstruction by cell fusion, $\mathrm{CF}$ ), or were injected directly into the ooplasm (reconstruction by cell injection, CI), according to Keefer et al. (2001) and Chen et al. (2007), respectively. Prior to injection into the ooplasm, cells were consecutively pipetted with a $12 \mu \mathrm{m}$ reconstruction pipette until a deformation of the cell membranes was visible.

For the reconstruction of ZF embryos, enucleated structures were incubated for 2 to $3 \mathrm{~min}$ in $500-\mu \mathrm{g} / \mathrm{ml}$ phytohemagglutinin (PHA) solution so that the cytoplast could adhere to the karyoplast, under stereomicroscope. All ZF embryos were reconstructed by membrane fusion.

For membrane fusion (ZI-CF and ZF-CF), reconstructed complexes were rinsed in fusion medium (Ribeiro et al., 2009), and then subjected to membrane fusion in an electrofusion apparatus (BTX Electro Cell Manipulator 200, Biotechnologies \& Experimental Research Inc., USA San Diego, CA, USA) coupled to a $320 \mu \mathrm{m}$ fusion chamber (BTX453, BTX Instruments, Genetronics, San Diego, CA, USA). The ZI structures were fused by two $2-\mathrm{kV} / \mathrm{cm}$ DC pulses for $20 \mu \mathrm{s}$, whereas the ZF structures received two $1-\mathrm{kV} / \mathrm{cm}$ DC pulses for $20 \mu \mathrm{s}$. Fusion rates were assessed 45 to 60 min after fusion. Non-fused structures were subjected to a second round of electrofusion.

\section{Use of cytochalasin $B$ during the embryonic activation}

Reconstructed embryos were submitted to two different protocols for embryo activation, based on Dutta et al. (2011), for protocol 1, and on Wells et al. (2011), for protocol 2, as follows. For the conventional protocol, or protocol 1, cloned embryos were exposed for $5 \mathrm{~min}$ to 5 $\mu \mathrm{m}$ ionomycin solution (I0634). Embryos were then incubated at $38.5^{\circ} \mathrm{C}$ for $4 \mathrm{~h}$ in TCM199 supplemented with $2 \mathrm{~mm}$ 6-DMAP (D2629). For the modified protocol, or protocol 2, structures were incubated for $2 \mathrm{~h}$ in $2.5 \mu \mathrm{g} / \mathrm{ml}$ cytochalasin $\mathrm{B}(\mathrm{CB})$ immediately after fusion evaluation, followed by the activation in $5 \mu \mathrm{m}$ ionomycin for $1 \mathrm{~min}$. Then, embryos were incubated in $2 \mathrm{~mm}$ 6-DMAP for $4 \mathrm{~h}$. Finally, cloned embryos were in vitro-cultured, as described below.

Experiment 2: Production of goat cloned embryos by handmade cloning: effects of the cytoplast source, karyoplast type, and final embryonic cytoplasmatic volume

Procedures for HMC were adapted from 
Ribeiro et al. (2009) for cattle and Pereira et al. (2013) for goats.

\section{Cytoplast source}

In vitro- and in vivo-matured COCs were subjected to enzymatic removal of the zona pellucida in $0.25 \%$ protease, as above.

\section{Embryonic cytoplasmatic volume}

Zona-free oocytes were sectioned manually in $2.5 \mu \mathrm{g} / \mathrm{ml}$ cytochalasin $\mathrm{B}$, depending on the presence or absence of the polar body (PB) or a protrusion cone (PC), indicative of the location of the MII plate. Oocytes without PB or PC were bissected in halves of equal sizes and volumes (50\% of the volume), whereas oocytes with $\mathrm{PB}$ or $\mathrm{PC}$ were sectioned at the extremity next to the $\mathrm{PB}$ or $\mathrm{PC}$, resulting in portions of approximately 85 and $15 \%$ of the original volume, with the smaller portion containing the MII plate. All hemioocytes were selected by the presence (nucleated) or absence (enucleated) of the MII plate under UV light, in TCM199 + 10\% of FBS $+10 \mu \mathrm{g} / \mathrm{ml}$ Hoechst 33342 . Embryos were reconstructed either with two $50 \%$ hemioocytes + donor cell $(50 \%+50 \%+$ cell $)$ or one $85 \%$ hemi-oocyte + donor cell $(85 \%+$ cell $)$.

\section{Karyoplast type}

Single hLZ-derived MSC or AF cells were used as karyoplasts for embryo reconstruction by attachment to enucleated in vivo- or in vitro-matured $\mathrm{ZF}$ hemi-oocytes with 50 or $85 \%$ cytoplasmatic volume, after a brief exposure to PHA solution, as aforementioned. Structures reconstructed by HMC were fused under the same fusion procedures as described above for ZF-embryos, followed by chemical activation by the conventional protocol (protocol 1), as above. HMC-derived embryos were in vitro-cultured, as described below.

\section{In vitro culture (IVC)}

Cloned embryos reconstructed by micromanipulation or by HMC were in vitro-cultured in modified SOFaa medium (Holm et al., 1999) supplemented with 5\% FBS $+0.3 \%$ BSA and $1 \%$ ITS, at $38.5^{\circ} \mathrm{C}$ with $100 \%$ relative humidity, and a gas mixture containing $5 \% \quad \mathrm{CO}_{2}, 5 \% \mathrm{O}_{2}$ and $90 \% \quad \mathrm{~N}_{2}$ (Ribeiro et al., 2009). For ZI cloned embryos, 15 to 20 structures were cultured in $100 \mu \mathrm{l}$ drops; in turn, ZF cloned embryos were cultured in a modified WOW system (Vajta et al., 2000; Feltrin et al., 2006) in 4-well dishes containing $500 \mu \mathrm{l}$ IVC medium. Prior to transfer to synchronous female recipients, cloned embryos reconstructed by micromanipulation were in vitrocultured for approximately $18 \mathrm{~h}$, whereas embryos reconstructed by HMC were in vitro-cultured for 7 days to the blastocyst stage.

In some procedures $(n=6)$, groups of $\mathrm{ZI}$ oocytes were kept under the same conditions as the structures reconstructed during cloning, to be chemically activated (conventional protocol, or protocol 1) and in vitro-cultured for 7 days, under the same conditions described above (control group by parthenogenesis).

\section{Estrous cycle synchronization of recipient females}

Recipient females were estrus synchronized by the use of intravaginal progesterone inserts (Eazi-Breed CIDR $^{\circledR}$, Laboratórios Pfizer Ltda., Brazil) for 10 days. At insert removal, $300 \mathrm{IU}$ eCG (Folligon $^{\circledR}$, Intervet, Brazil) and $0.075 \mathrm{mg}$ PGF2 $\alpha$ (Prolise ${ }^{\circledR}$, ARSA S.R.L., Argentina) were given IM. A dose of $0.025 \mathrm{mg}$ gonadorelin acetate (Gestran ${ }^{\circledR}$, ARSA S.R.L., Argentina) and $25 \mathrm{mg}$ LH (Lutropin ${ }^{\circledR}$, Bioniche, Brazil) were given IM 36 and $60 \mathrm{~h}$ after eCG administration, respectively.

\section{Embryo transfer (ET) and pregnancy diagnosis:} embryos reconstructed by micromanipulation

Cloned embryos at the 1-cell stage were transferred to the oviduct of recipient females on day 1 of the cycle by semi-laparoscopy, approximately $8 \mathrm{~h}$ after the LH dose. The mean number of embryos transferred per female was 13.4 , with a variation of 11 to 25 embryos per recipient. On the 4th day after the embryo transfer, an intravaginal progesterone insert (Eazi-Breed CIDR ${ }^{\circledR}$, Laboratórios Pfizer Ltda., Brazil) was placed in the female recipients and remained until pregnancy diagnosis. The progesterone insert was replaced weekly until day 140 of the pregnancy, or until the detection of a non-viable pregnancy (no pregnancy after diagnosis or after detection of conceptus death).

Embryo transfer (ET) and pregnancy diagnosis: embryos reconstructed by $H M C$

Cloned goat embryos on days 7 of development were transferred to synchronous female recipients (4 to 6 embryos/female), by semilaparoscopy, to the uterine horn ipsilateral to the ovary with a functional corpus luteum, according to Melican and Gavin (2008). This group of female recipients did not receive any progesterone supplementation (intravaginal inserts) after the transfer of embryos.

Pregnancy diagnosis was performed on day 23 by rectal ultrasonography using a $6 \mathrm{MHz}$ linear transducer. Pregnancies were monitored by ultrasound scanning every 3-4 days until no sign of pregnancy was displayed or for confirmation of pregnancy viability. For viable pregnancies, a transabdominal ultrasound examination was repeated at weekly intervals from the 35 th day of pregnancy through term. The presence of one or more embryos or fetuses, detectable heart beat, embryonic or fetal membranes, and placentomes were examined qualitatively.

\section{Data analysis}

Data relative to in vitro survival, fusion and 
pregnancy rates were compared between the experimental groups by the Chi-square test (Minitab, State College, PA, USA), for $\mathrm{P}<0.05$, for cloning by micromanipulation (experiment 1) or by HMC (experiment 2), considering oocyte source (in vivo vs. in vitro) and cell type (MSC vs. FF vs. AF for micromanipulation, and $\mathrm{MSC} v s$. AF for cloning by HMC). For cloning by micromanipulation, the analyses also considered the type of manipulation (ZI vs. ZF), reconstruction ( $\mathrm{CF}$ vs. $\mathrm{CI}$ ), embryonic activation protocol (1 vs. 2), and the proportion of cells at different phases of the cell cycle (G0/G1 vs. S vs. G2/M), whereas for cloning by HMC, the analyses also included data on the final cytoplasmic volume (85 vs. 100\%). Data regarding the number of retrieved COCs per animal, for both cloning methods, were compared by the Students' test $(\mathrm{P}<0.05)$.

\section{Results}

Experiment 1: Embryo reconstruction by
micromanipulation

\section{Cytoplast source}

For in vitro-matured oocytes, after 16 replications, a total of 4,138 immature COCs (19.9 COCs/goat) were recovered by post-mortem ovary slicing from 415 ovaries collected from non-stimulated slaughterhouse does. Upon morphological selection, 20 grade I $(1.0 \%), 380$ grade II $(18.9 \%), 1,255$ grade III $(62.4 \%)$ and 509 grade IV $(20.2 \%)$ oocytes $(2,164$ viable COCs, 52.3\%) were in vitro-matured (10.4 $\mathrm{COCs} /$ female). After IVM, the maturation rate, based on the presence of the PB, was $83.6 \%(17 / 20), 60.2 \%$ (228/380), 43.5\% (546/1255) and 30.2\% (153/509), for grades I, II, III and IV COCs, respectively, for a total maturation rate of $48.4 \%(1,047 / 2,164)$ and mean of 5.0 matured oocytes/female. For in vivo-matured oocytes, after seven replications, a total of 974 COCs (14.3 $\mathrm{COCs} /$ female) were recovered after the in vivo aspiration of pre-ovulatory follicles from 136 ovaries from $\mathrm{pFSH}$-stimulated females. Upon selection, 937 COCs (96.2\%) had cumulus cells expansion (13.8 oocytes/goat), and 741 oocytes displayed the extrusion of the 1 st $\mathrm{PB}$, resulting in a maturation rate of $52.6 \%$ and 7.3 mature oocytes/female. The maturation rate and the number of matured oocytes/female were significantly higher in the group of in vivo-matured oocytes when compared with the group of in vitromatured COCs $(\mathrm{P}<0.05)$. However, when used for embryo reconstruction by micromanipulation, survival rate after enucleation and after reconstruction per se was higher in the in vitro-matured group than the in vivomatured counterpart (Table 1), with no differences observed in pregnancy rates between groups.

A total of 120 in vitro-matured oocytes obtained from samples from each replication were chemically activated and in vitro-cultured as control for the manipulation process per se and for oocyte quality/competence, from which, 75 cleaved $(62.5 \%)$ and 22 reached the morula/blastocyst stages $(18.3 \%)$ on day 7 of development.

Table 1. Survival rates after manipulation and embryo reconstruction following cloning by micromanipulation in goats using oocytes obtained either by in vitro-maturation after postmortem oocyte collection from nonstimulated females, or by in vivo-maturation after in vivo oocyte collection from FSH-stimulated females.

\begin{tabular}{|c|c|c|c|c|}
\hline \multirow{2}{*}{$\begin{array}{c}\text { Oocyte source } \\
\text { Survival }\end{array}$} & \multicolumn{2}{|c|}{$\begin{array}{l}\text { Postmortem collection, } \\
\text { nonstimulated does, in } \\
\text { vitro-matured oocytes }\end{array}$} & \multicolumn{2}{|c|}{$\begin{array}{c}\text { In vivo collection, } \\
\text { FSH-stimulated does, } \\
\text { in vivo-matured } \\
\text { oocytes }\end{array}$} \\
\hline & $\mathrm{n}$ & $\%$ & $\mathrm{n}$ & $\%$ \\
\hline Micromanipulated oocytes & 903 & - & 444 & - \\
\hline Enucleated oocytes & 808 & $89.5^{\mathrm{a}}$ & 362 & $81.5^{\mathrm{b}}$ \\
\hline Reconstructed embryos & 793 & $98.1^{\mathrm{a}}$ & 340 & $93.9^{\mathrm{b}}$ \\
\hline Fusion or cell injection & 700 & $88.3^{\mathrm{a}}$ & 282 & $82.9^{\mathrm{b}}$ \\
\hline Viable embryos in IVC & 649 & $92.7^{\mathrm{a}}$ & 275 & $97.5^{\mathrm{b}}$ \\
\hline Viable embryos transferred & 561 & $86.4^{\mathrm{a}}$ & 221 & $80.3^{\mathrm{b}}$ \\
\hline Recipient females diagnosed pregnant on day 23 , from total & $31 / 40$ & $77.5^{\mathrm{a}}$ & $14 / 18$ & $77.8^{\mathrm{a}}$ \\
\hline
\end{tabular}

${ }_{\mathrm{a}, \mathrm{b}}$ numbers in each row followed by different superscripts differ, for $\mathrm{P}<0.05$.

\section{Type of karyoplast and cell cycle phase}

No differences were observed in fusion rates and in the number of viable embryos for IVC between cell types used for the production of cloned embryos (MSC, FF, AF). After the IVC, the number of viable embryos was greater in the group derived from FF cells than in the other groups. However, pregnancy rate was higher in the groups of embryos produced using $\mathrm{FF}$ and MSCs when compared with AF cells (Table 2).
Differences $(\mathrm{P}<0.05)$ were detected between cell types regarding the distribution in the phases of the cell cycle, as depicted in Figure 1. The synchronization of the cell cycle in the G0/G1 phase in the adult fibroblast (AF) group was greater than in the fetal fibroblast (FF) group, which, in turn, was greater than for mesenchymal stem cells (MSC), which showed a relationship with the mean cell confluence for each cell type $(>95,80-90$ and $60-70 \%$, respectively) when used for cloning. 


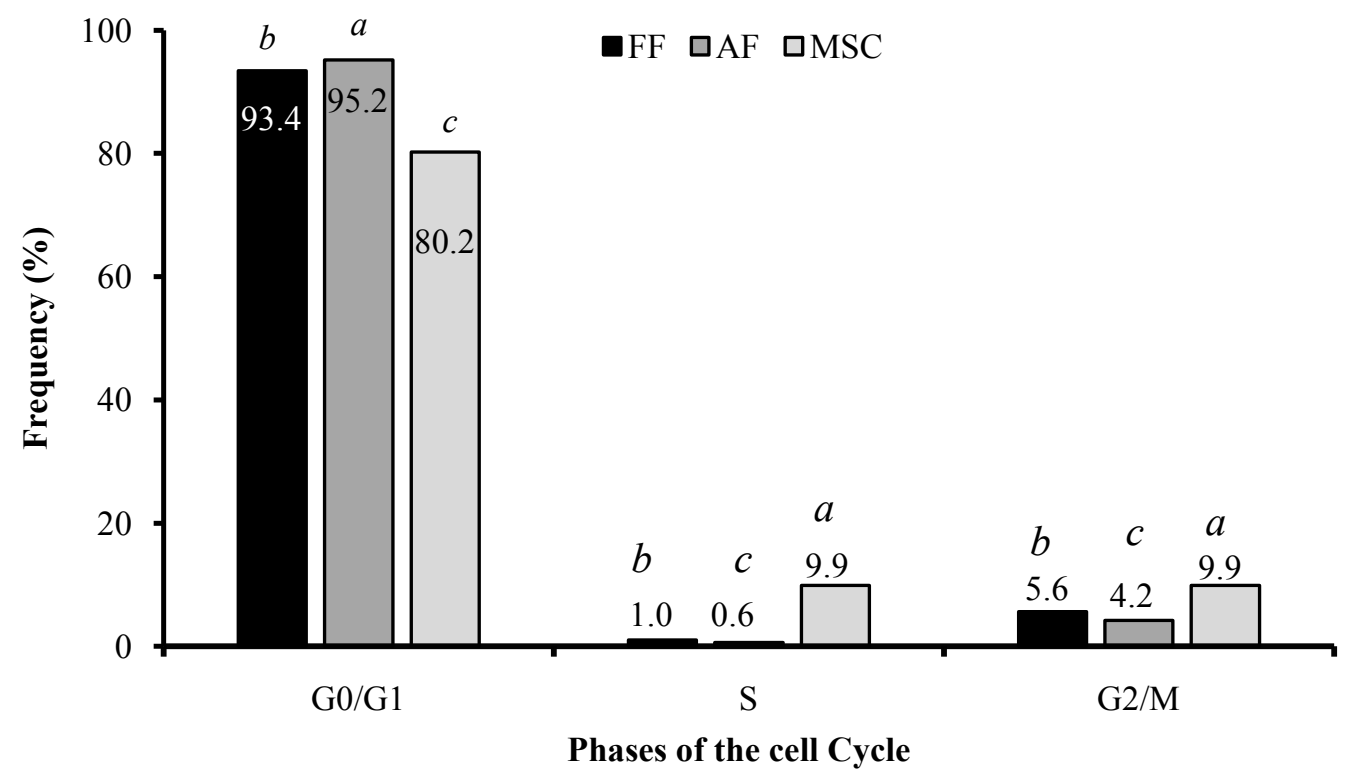

Figure 1. Distribution of cells in the phases of the cell cycle (G0/G1, S, G2/M) in goat donor cells used for cloning. FF: fetal fibroblasts, $80-90 \%$ confluence. AF: adult fibroblasts, $>95 \%$ confluence. MSC: mesenchymal stem cells, $60-70 \%$ confluence. Numbers within or above columns indicate values in percentage. ${ }^{\mathrm{a}, \mathrm{b}, \mathrm{c}}$ columns in each phase of the cell cycle with distinct superscripts differ $(\mathrm{P}<0.05)$.

Table 2. In vitro and in vivo survival of reconstructed embryos using fetal fibroblasts (FF), adult fibroblast (AF), or bone marrow-derived mesenchymal stem cells (MSC) as nucleus donor cells for cloning by micromanipulation in goats.

\begin{tabular}{lcccccc}
\hline \multicolumn{1}{c}{ Cell type } & \multicolumn{2}{c}{ FF } & \multicolumn{2}{c}{ AF } & \multicolumn{2}{c}{ MSC } \\
\cline { 2 - 7 } & $\mathrm{n}$ & $\%$ & $\mathrm{n}$ & $\%$ & $\mathrm{n}$ & $\%$ \\
\hline Reconstructed embryos & 251 & - & 686 & - & 196 & - \\
Fusion efficiency & 223 & $88.8^{\mathrm{a}}$ & 594 & $86.6^{\mathrm{a}}$ & 172 & $87.7^{\mathrm{a}}$ \\
Viable embryos in IVC & 208 & $93.2^{\mathrm{a}}$ & 548 & $92.2^{\mathrm{a}}$ & 164 & $95.3^{\mathrm{a}}$ \\
Viable embryos transferred & 192 & $92.3^{\mathrm{a}}$ & 452 & $82.5^{\mathrm{b}}$ & 138 & $84.1^{\mathrm{b}}$ \\
Recipient females diagnosed pregnant on day 23 & $14 / 15$ & $93.3^{\mathrm{a}}$ & $22 / 34$ & $64.7^{\mathrm{b}}$ & $9 / 9$ & $100.0^{\mathrm{a}}$ \\
\hline
\end{tabular}

a,b numbers in each row followed by different superscripts differ, for $\mathrm{P}<0.05$.

\section{Removal of zona pellucida}

Considering the presence or removal of the $\mathrm{ZP}$, the post-enucleation survival, the fusion/microinjection rate and the number of viable embryos after reconstruction by micromanipulation were higher in the ZI group when compared to the ZF group. However, no differences were seen in pregnancy rates between groups (Table 3).

\section{Method for nucleus donor transfer}

The survival rate after reconstruction by micromanipulation was greater in the group of cell microinjection (CI) into the ooplasm when compared with the group of cell fusion $(\mathrm{CF})$, irrespective of the presence $(\mathrm{ZI})$ or absence $(\mathrm{ZF})$ of the $\mathrm{ZP}(\mathrm{P}<0.05)$. However, no significant differences in pregnancy rates were observed between groups (Table 4).

Table 3. Effect of the presence (ZI) or removal (ZF) of the zona pellucida on survival after enucleation and embryo reconstruction by micromanipulation procedures for cloning by SCNT in goats.

\begin{tabular}{lcccc}
\multicolumn{1}{c}{ Micromanipulation method } & Zona-intact oocytes (ZI) & \multicolumn{2}{c}{ Zona-free oocytes (ZF) } \\
\cline { 2 - 5 } & $\mathrm{n}$ & $\%$ & $\mathrm{n}$ & $\%$ \\
\hline Micromanipulated oocytes & 675 & - & 672 & - \\
Enucleated oocytes & 603 & $89.3^{\mathrm{a}}$ & 567 & $84.4^{\mathrm{b}}$ \\
Reconstructed embryos & 580 & $96.2^{\mathrm{a}}$ & 553 & $97.5^{\mathrm{a}}$ \\
Fusion or cell injection & 535 & $92.2^{\mathrm{a}}$ & 449 & $81.2^{\mathrm{b}}$ \\
Viable embryos in IVC & 517 & $99.2^{\mathrm{a}}$ & 407 & $90.6^{\mathrm{b}}$ \\
Viable embryos transferred & 445 & $86.0^{\mathrm{a}}$ & 337 & $82.8^{\mathrm{a}}$ \\
Recipient females diagnosed pregnant on Day 23, from total & $26 / 33$ & $78.8^{\mathrm{a}}$ & $19 / 25$ & $76.0^{\mathrm{a}}$ \\
\hline
\end{tabular}

\footnotetext{
${ }^{\mathrm{a}, \mathrm{b}}$ numbers in each row followed by different superscripts differ, for $\mathrm{P}<0.05$.
} 
Feltrin et al. Factors affecting goat cloning efficiency.

Table 4. In vitro survival and pregnancy outcome of goat cloned embryos after embryo reconstruction by micromanipulation and transfer to female recipients on day 1 of development

\begin{tabular}{|c|c|c|c|c|c|c|c|c|}
\hline \multirow{2}{*}{$\begin{array}{l}\text { Oocyt } \\
\text { e type }\end{array}$} & \multirow{2}{*}{$\begin{array}{c}\text { Cell fusion } \\
(\mathrm{CF}) \text { or cell } \\
\text { injection }(\mathrm{CI})\end{array}$} & \multirow{2}{*}{$\begin{array}{c}\begin{array}{c}\text { Reconstructed } \\
\text { structures }\end{array} \\
\mathrm{n}\end{array}$} & \multicolumn{2}{|c|}{$\begin{array}{c}\text { Survival after } \\
\text { CF or CI }\end{array}$} & \multirow{2}{*}{$\begin{array}{c}\text { Transferred } \\
\text { embryos }\end{array}$} & \multirow{2}{*}{$\frac{\text { Recipients }}{\mathrm{n}}$} & \multicolumn{2}{|c|}{$\begin{array}{l}\text { Pregnancy rate } \\
\text { (day 23) }\end{array}$} \\
\hline & & & $\mathrm{n}$ & $\%$ & & & $\mathrm{n}$ & $\%$ \\
\hline ZI & $\mathrm{CI}$ & 232 & 222 & $95.6^{\mathrm{a}}$ & 193 & 14 & 11 & $78.5^{\mathrm{a}}$ \\
\hline ZI & $\mathrm{CF}$ & 348 & 295 & $84.7^{b}$ & 252 & 19 & 15 & $78.9^{\mathrm{a}}$ \\
\hline $\mathrm{ZF}$ & $\mathrm{CF}$ & 553 & 407 & 73.6 & 337 & 25 & 19 & $76.0^{\mathrm{a}}$ \\
\hline
\end{tabular}

${ }^{\mathrm{a}, \mathrm{b}}$ numbers in each column followed by different superscripts differ, for $\mathrm{P}<0.05$. ZI: zona intact; ZF: zona free; CF: cell fusion; CI: cell injection.

\section{Activation protocol}

When comparing the activation protocol, pregnancy rates on day 23 after the reconstruction by micromanipulation was higher in the group of embryos activated by the Conventional Protocol, or protocol 1 , when compared with the activation protocol with $\mathrm{CB}$, or protocol 2 (Table 5).

Table 5. In vitro survival and pregnancy outcome of goat cloned embryos after embryo reconstruction by micromanipulation and embryo activation using either a conventional or a modified activation protocol.

\begin{tabular}{lcccc}
\hline Activation protocol & \multicolumn{2}{c}{ Conventional (1) } & \multicolumn{2}{c}{ Modified (2) } \\
\cline { 2 - 5 } & $\mathrm{n}$ & $\%$ & $\mathrm{n}$ & $\%$ \\
\hline Activated embryos & 727 & - & 255 & - \\
Viable embryos in IVC & 687 & $94.5^{\mathrm{a}}$ & 237 & $92.9^{\mathrm{a}}$ \\
Viable embryos transferred & 591 & $86.0^{\mathrm{a}}$ & 191 & $80.6^{\mathrm{b}}$ \\
Recipient females diagnosed pregnant on day 23 & $37 / 42$ & $88.1^{\mathrm{a}}$ & $8 / 16$ & $50.0^{\mathrm{b}}$ \\
\hline
\end{tabular}

${ }^{\mathrm{a}, \mathrm{b}}$ numbers in each row followed by different superscripts differ, for $\mathrm{P}<0.05$.

Experiment 2: Embryo reconstruction by handmade cloning

\section{Cytoplast source}

The summary of results after reconstruction by $\mathrm{HMC}$, after 10 replications, is presented in Tables 6 and 7. A total of 50 and 106 goats (99 and 211 ovaries, respectively) were used to obtain in vivo- and in vitromatured oocytes, respectively. No differences were observed in the mean number of recovered COCs (17.8 vs. 20.6/female) and viable oocytes (14.2 vs. $13.1 /$ female) between non-stimulated donor females (in vitro maturation) and hormonally superstimulated does (in vivo maturation), respectively. The recovery rate for total COCs was higher from non-stimulated goats $(1,880 / 2,095$ follicles, $89.7 \%)$ than from the hormonally stimulated group (1,019/1,178 follicles, 86.5\%). Moreover, the proportion of viable COCs and the oocyte maturation rate (presence of polar body) were significantly higher in the in vitro group than in the in vivo group (Table 6). However, the source of oocytes was not associated with differences in in vitro (Table 7) or in vivo development of cloned goat embryos, irrespective of the other experimental variables, resulting in similar fusion $(76 / 115,66.1 \%$ vs. $193 / 274$, $70.4 \%$ ), re-fusion $(18 / 35,51.4 \%$ vs. $34 / 77,44.2 \%)$, cleavage $(66 / 94,70.2 \%$ vs. $163 / 227,71.8 \%)$ and blastocyst $(26 / 94,27.7 \%$ vs. 70/227, 30.8\%) rates for in vivo-vs. in vitro-matured oocytes, respectively.

Table 6. Recovery and maturation rates using oocytes obtained in vivo from pFSH-stimulated females (in vivo maturation) or postmortem from nonstimulated females (in vitro maturation) for embryo reconstruction by Handmade Cloning.

\begin{tabular}{cccccc}
\hline \multirow{2}{*}{ Oocyte source } & Total COCs & \multicolumn{2}{c}{ Viable COCs } & \multicolumn{2}{c}{ Oocytes with polar body* } \\
\cline { 2 - 6 } & $\mathrm{n}$ & $\mathrm{N}$ & $\%$ & $\mathrm{n}$ & $\%$ \\
\hline In vivo & 1,019 & 703 & $69.0^{\mathrm{b}}$ & 312 & $44.4^{\mathrm{b}}$ \\
In vitro & 1,880 & 1,380 & $73.4^{\mathrm{a}}$ & 727 & $52.7^{\mathrm{a}}$ \\
\hline Total & 2,899 & 2,083 & 71.9 & 1,039 & 49.9 \\
\hline
\end{tabular}

${ }^{\mathrm{a}, \mathrm{b}}$ numbers in each row followed by different superscripts differ, for $\mathrm{P}<0.05$. *Based on the number of recovered viable COCs.

\section{Type of karyoplast}

In general, the type of karyoplast or cytoplast did not affect any in vitro and in vivo embryonic development parameter, with no significant differences detected between groups regarding in vitro embryo development until day 7 (Table 7). When analyzed separately, embryo reconstruction using mesenchymal stem cells (MSC) resulted in higher fusion rates than using adult fibroblasts (160/198, 80.8\% vs. 119/191, $62.3 \%$, respectively), with no differences in re-fusion (24/43, 55.8\% vs. $28 / 69,40.6 \%)$, cleavage (128/174, $73.6 \%$ vs. $101 / 147,68.7 \%)$ and blastocyst $(58 / 174$, $33.3 \%$ vs. $38 / 147,25.9 \%$ ) rates. 
Feltrin et al. Factors affecting goat cloning efficiency.

Table 7. In vitro development of goat embryos cloned by Handmade Cloning.

\begin{tabular}{|c|c|c|c|c|c|c|c|c|c|c|c|}
\hline \multirow{2}{*}{$\begin{array}{l}\text { Oocyt } \\
\mathrm{e} \\
\text { source }\end{array}$} & \multirow{2}{*}{$\begin{array}{c}\text { Donor } \\
\text { cell type }\end{array}$} & \multirow{2}{*}{$\begin{array}{l}\text { Cytoplasmic } \\
\text { volume }\end{array}$} & \multirow{2}{*}{$\begin{array}{l}\text { Cloned } \\
\text { embryos }\end{array}$} & \multicolumn{2}{|c|}{ Fusion } & \multicolumn{2}{|c|}{ Re-fusion } & \multicolumn{2}{|c|}{ Cleavage rate } & \multicolumn{2}{|c|}{ Blastocyst rate } \\
\hline & & & & $\mathrm{n}$ & $\%$ & $\mathrm{n}$ & $\%$ & $\mathrm{n}$ & $\%$ & $\mathrm{n}$ & $\%$ \\
\hline \multirow{4}{*}{$\begin{array}{c}\text { In } \\
\text { vivo }\end{array}$} & \multirow{2}{*}{ MSC } & $100 \%$ & 32 & 27 & $84.4^{\mathrm{a}}$ & $2 / 5$ & $40.0^{\mathrm{a}}$ & $23 / 29$ & $79.3^{\mathrm{a}}$ & $11 / 29$ & $37.9^{\mathrm{a}}$ \\
\hline & & $85 \%$ & 32 & 18 & $58.1^{\mathrm{b}}$ & $8 / 13$ & $61.5^{\mathrm{a}}$ & $17 / 26$ & $65.4^{\mathrm{a}}$ & $6 / 26$ & $23.1^{\mathrm{a}}$ \\
\hline & \multirow{2}{*}{$\mathrm{AF}$} & $100 \%$ & 27 & 18 & $66.7^{\mathrm{ab}}$ & $4 / 9$ & $44.4^{\mathrm{a}}$ & $16 / 22$ & $72.7^{\mathrm{a}}$ & $6 / 22$ & $27.3^{\mathrm{a}}$ \\
\hline & & $85 \%$ & 24 & 13 & $54.2^{\mathrm{b}}$ & $4 / 8$ & $50.0^{\mathrm{a}}$ & $10 / 17$ & $58.8^{\mathrm{a}}$ & $3 / 17$ & $17.3^{\mathrm{a}}$ \\
\hline \multirow{4}{*}{$\begin{array}{c}\text { In } \\
\text { vitro }\end{array}$} & \multirow{2}{*}{ MSC } & $100 \%$ & 92 & 72 & $78.3^{\mathrm{a}}$ & $11 / 18$ & $61.1^{\mathrm{a}}$ & $63 / 83$ & $75.9^{\mathrm{a}}$ & $29 / 83$ & $34.9^{\mathrm{a}}$ \\
\hline & & $85 \%$ & 42 & 33 & $78.6^{\mathrm{b}}$ & $3 / 7$ & $42.9^{\mathrm{a}}$ & $25 / 36$ & $69.4^{\mathrm{a}}$ & $12 / 36$ & $33.3^{\mathrm{a}}$ \\
\hline & \multirow{2}{*}{$\mathrm{AF}$} & $100 \%$ & 88 & 54 & $61.4^{\mathrm{ab}}$ & $13 / 36$ & $36.1^{\mathrm{a}}$ & $50 / 68$ & $73.5^{\mathrm{a}}$ & $19 / 68$ & $27.9^{\mathrm{a}}$ \\
\hline & & $85 \%$ & 52 & 34 & $65.4^{\mathrm{ab}}$ & $7 / 16$ & $45.8^{\mathrm{a}}$ & $25 / 40$ & $62.5^{\mathrm{a}}$ & $10 / 40$ & $25.0^{\mathrm{a}}$ \\
\hline Total & & & 389 & 269 & 69.3 & $52 / 119$ & 43.7 & $229 / 321$ & 71.3 & $96 / 321$ & 29.9 \\
\hline
\end{tabular}

${ }^{\mathrm{a}, \mathrm{b}}$ numbers in each column followed by different superscripts differ, for $\mathrm{P}<0.05$. MSC: mesenchymal stem cells. AF adult fibroblasts.

\section{Final cytoplasmic volume}

No differences were observed in final cytoplasmic volume for embryo reconstruction for fusion $(171 / 239,71.5 \%$ vs. 98/150, 65.3\%), re-fusion $(30 / 68,44.1 \%$ vs. $22 / 44, \quad 50.0 \%)$, and blastocyst $(65 / 202,32.2 \%$ vs. $31 / 119,26.1 \%)$ rates, irrespective of the oocyte source and cell type used for cloning. However, the final cytoplasmic volume of $100 \%$ (50\% $+50 \%+$ donor cell) resulted in higher cleavage rates $(152 / 202,75.2 \%)$ than with $85 \%(77 / 119,64.7 \%)$. Embryo reconstruction using oocytes with $85 \%$ of the final cytoplasmic volume and MSCs resulted in lower fusion rates than after the reconstitution of $100 \%$ of the oocyte volume and MSCs, with no differences between groups when AF cells were used for cloning, independently of the cytoplasmic volume and oocyte source (Table 7). Also, no differences were observed between groups in re-fusion, cleavage and blastocyst rates.

In vivo embryo development and birth of a cloned goat

\section{Embryos reconstructed by micromanipulation}

Collectively, 782 cloned embryo were transferred on day 1 of development to the oviduct of 58 synchronous recipient females, resulting in 45 pregnancies $(45 / 58,77.0 \%)$ on day 23 of gestation. However, all established pregnancies with transgenic human lysozyme (hLZ) cells, in all groups and subgroups, were lost before the fetal phase (up to day 45) of gestation. Nevertheless, after the induction of parturition following our established protocol (Chavatte-Palmer et al., 2013), a viable cloned female was born by elective Caesarean section after 147 days of gestation from the transfer of 27 embryos cloned with non-transgenic control cells to two female recipients. The cloned female was generated from the reconstruction by micromanipulation with control cells (non-transgenic fetal fibroblasts), using in vitro-matured oocytes with zona pellucida $(\mathrm{ZI})$, reconstructed by membrane fusion $(\mathrm{CF})$, activated by the conventional protocol (P1) and transferred on day 1 of development to the oviduct of a female recipient that had received a vaginal progesterone insert throughout pregnancy.

\section{Embryos reconstructed by $H M C$.}

A total of 96 goat blastocysts were transferred on day 7 of development to the uterus of 19 synchronous females. The pregnancy diagnosis, performed by ultrasound on day 23 of gestation, resulted in three pregnancies originated from in vivo$(\mathrm{n}=1)$ and in vitro-matured $(\mathrm{n}=2)$ oocytes, from which, two were obtained using mesenchymal stem cells and one through the use of adult fibroblasts. The three pregnancies were lost before day 45 of gestation.

\section{Discussion}

Although cloning by SCNT is well established in goats, with birth rates similar to those found in other species, there are no reports of cloned goats born in the tropics of the world, between parallels $30^{\circ} \mathrm{N}$ and $30^{\circ} \mathrm{S}$, with all cloned goats born in countries under temperate or subtropical climates (Baguisi et al., 1999; Keefer et al., 2001; Reggio et al., 2001; Ohkoshi et al., 2003; Lan et al., 2006; Chen et al., 2007; Folch et al., 2009; Akshey et al., 2010; Colato et al., 2011; Liu et al., 2011; Nasr-Esfahani et al., 2011; Wells et al., 2011; Meng et al., 2012; An et al., 2012; Zhou et al., 2013; Yuan et al., 2014; Feng et al., 2015; Hosseini et al., 2015; Zhang et al., 2015; Yang et al., 2016a; Bai et al., 2017). This fact may be associated with the low productive and reproductive indexes of goat herds in tropical countries, such as in the Brazilian Semi-Arid region, where the annual birth rate in goats does not exceed 20\% (Guimarães, 2006).

The oocyte quality and competence play a 
crucial role in the success of a cloning program, since the ooplasm is responsible for reprogramming the nucleus donor, which has an important effect on subsequent development (Fissore et al., 1999; Kelly et al., 2007; Mohapatra et al., 2015). Normally, better quality oocytes, usually grades I (GI) and II (GII), are selected for in vitro maturation (Chen et al., 2007; Tang et al., 2011). When analyzing data regarding the quality of immature COCs in this study, less than $20 \%$ of selected COCs were rated as GI and GII, with a large portion of the COCs lacking or having little cumulus cells vestment. Previous studies have shown that body condition score, physiological conditions of the egg donor, breed, age and individual variations directly interfere with the quality of the recovered COCs (Edwards and Hansen, 1996; Vinoles et al., 2002; Fatehi et al., 2005; Cecconi et al., 2007). In addition, the absence of significant variation in the photoperiod throughout the year, the low rainfall, or even the high temperatures in equatorial or tropical zones, may cause a reduction in the quality of goat COCs (Jordan, 2003; Chaves et al., 2010, 2011). According to Roth and Hansen (2004), inter- and intra-cellular components define how an oocyte will react to effects from the environment and high temperatures, even if within physiological ranges, potentially even being a stimulus to apoptosis in mammalian oocytes. A fact that corroborates this assertion is that the rate of development of parthenogenetic embryos to the morula and blastocyst stages obtained in our experiment was $18.3 \%$, a low value for oocytes previously selected for the presence of the 1st PB extrusion and cytoplasm morphology when compared with studies by Apimeteetumrong et al. (2004) and Nasr-Esfahani et al. (2011), who obtained 42.3 and $54.9 \%$ of parthenogenetic development to the morula and blastocyst stages, and to the blastocyst stage, respectively. The animal response to climatic elements and factors may play an influence in the results of this study, resulting in a low overall efficiency of cloning under our conditions. Nevertheless, we obtained approximately $30 \%$ of embryonic development to the blastocyst stage after VC of embryos cloned by HMC. However, these embryos exhibited low morphological quality (data not shown), which is commonly reflected in lower rates of in vivo development (Pereira et al., 2013), as observed in this study.

Based on the morphological features of the collected COCs, one of the alternatives attempted to improve results was the use of in vivo-matured oocytes. However, this issue seems to be controversial, since while Reggio et al. (2001) found no differences between in vitro- and in vivo-matured oocytes, showing that both oocyte sources were similar in competence to support in vivo development after goat cloning, whereas Behboodi et al. (2004) and Martins et al. (2016) did not obtain pregnancies after the transfer of cloned embryos using in vitro-matured oocytes. Unlike Reggio et al. (2011), our experiment found that nuclear maturation rate was higher in the group of in vitro-matured oocytes than the in vivo-matured counterparts. However, the nuclear maturation rate only takes into account the extrusion of the 1 st $\mathrm{PB}$, which is not the only factor to be considered to determine oocyte quality and competence. As for findings by Reggio et al. (2011), no differences in pregnancy rates were observed between the oocyte source, which may indicate that the in vitro protocols for nuclear maturation are rather well established for goats, with attained pregnancy rates similar (Baldassare et al., 2004) to those found for other species.

In this study, two distinct SCNT cloning micromanipulation methods were compared for the production of clone embryos, with the use of conventional cloning with (ZI) or without (ZF) zona pellucida (ZP). Cloning by micromanipulation with the $\mathrm{ZP}$ is in more widespread use in the world for goats, with the ZP maintained until the end of the procedure (Keefer et al., 2001; Chavatte-Palmer et al., 2013). However, this technique requires greater skills from the operator than the zona-free method, since the presence of the $\mathrm{ZP}$ imposes an extra challenge for the aspiration of the MII plate and the PB (Peura, 2003). The ZF technique, on the other hand, should be an easier process, as the enucleation is more straightforward, which is further facilitated as there is no need for another micromanipulation step for the reconstruction of embryos by cell insertion (Booth et al., 2001; Hosseini et al., 2015). Although embryo production rates using both techniques are similar, the $\mathrm{ZF}$ procedure enables the production of a greater number of embryos per routine (Booth et al., 2001; Peura, 2003). In our case, the post-enucleation survival, the fusion/microinjection rate and the number of viable embryos were higher in the ZF group than the ZI group. However, no differences were observed in pregnancy rates between groups.

The cell type, cycle synchronization, lineage and time in culture, among other factors, are known to be crucial for the cloning outcome (Dominko et al., 1999; Yang et al., 2016b). Keefer et al. (2001) used three different GFP transgenic cell lines to clone goats, and found that only one line was capable of producing viable animals. In that same study, the group used five different lines of fetal fibroblasts, and only two were able to generate viable cloned animals. According to Baldassare et al. (2004), pregnancy rates varied from 0 to $89 \%$ when using different cell lines for SCNT cloning, demonstrating the high variability in results when different cell lines are used. In our experiment, after the IVC period, the number of embryos suitable for transfer was higher in the group of fetal fibroblasts (FF) than the other groups. However, pregnancy rates were higher for embryos produced with fetal fibroblasts (FF) and mesenchymal stem cells (MSC). In addition, similarly to what was observed by Chen et al. (2007), survival rate after reconstruction was greater when cells were microinjected in the ooplasm than cell fusion, irrespective of the presence or removal of the zona pellucida.

In the group of embryos produced by the $\mathrm{HMC}$, the final cytoplasmic volume of $100 \%$ resulted in higher cleavage rates than with $85 \%$. We have previously seen that the reduction of cytoplasmic volume to $50 \%$ of the final volume significantly 
compromises in vitro development and embryo kinetics of cloned bovine embryos, with the reduction of the total number of cells in blastocysts (Ribeiro et al., 2009). Because the cytoplast plays a key role in chromatin remodeling, the effect of the cytoplasmic volume after cloning cannot be neglected. Previous studies also corroborate the effect of the reduction or increase of the cytoplasmic volume on embryonic development. The removal of 50 or $25 \%$ of ooplasm during enucleation compromised embryonic development and quality and the total number of cells in cloned bovine blastocysts (Westhusin et al., 1996; Peura et al., 1998; Ribeiro et al., 2009). In conditions where the volume is reduced, the amount of ooplasmic components probably will not be sufficient to support cleavage, activation of the embryonic genome, or even cavitation, but since the cytoplasmatic volume does not increase during the first cycles of cell division, the total number of cells tends to be limited by the total volume of the developing embryo (Westhusin et al., 1996; Ribeiro et al., 2009).

Although embryonic vesicles have been observed from day 23 of development in all groups, no heart beats could be observed in most cases. Such nonviable structures often remained until day 50 of gestation, when the progesterone inserts were removed. After a few days, the structures could no longer be observed. These findings corroborate with Baguisi et al. (1999) and Zhang et al. (2010). According to Baguisi et al. (1999), more than $2 / 3$ of their clone pregnancies were not viable, and such "embryonic structures" were observed in the uterus until day 55 of gestation. In our case, out of 45 embryonic structures, the heartbeat could only be observed in five cases. Several factors may have contributed to these findings, including failures in placentation and/or embryonic genome activation, or even in the enucleation process, which could lead to the transfer of polyploid embryos in rare cases (Baguisi et al., 1999). Collectively, the overall efficiency of cloning under our conditions was $0.11 \%$, considering the number of transferred embryos (1/809) to obtain one live born animal, which is significantly lower than what was previously reported in the literature (Keefer et al., 2001, 2002; Baldassare et al., 2004), even for transgenic cloned kids (Gavin et al., 2013; Feng et al., 2015).

The high rate of pregnancy losses observed in this study may have been caused by the cell types and lines used for cloning, the low oocyte quality and inefficient genomic reprogramming, and even by technical aspects inherent to SCNT cloning per se. More studies are needed to investigate such aspects, as observed during this experiment. In addition to the potential failures, the high pregnancy rates verified in this work in all groups may also be related to the use of the progesterone insert from the 4th day after the embryo transfer, which could have prevented the return to the natural estrous cycle, 'rescuing' less viable embryos that would otherwise be unable to trigger the maternal recognition of pregnancy, an event already proposed by Bertolini et al. (2002) for in vitro-derived bovine embryos. In fact, a pilot study carried out by our group using progesterone supplementation (intravaginal inserts) on day 4 after the artificial insemination of female goats as a way to increase pregnancy rates resulted in $41.7 \%(5 / 12)$ and $80.0 \%(8 / 10)$ pregnancy in the control and in the progesterone-treated groups, respectively (Feltrin \& Bertolini, 2011, University of Fortaleza; unpublished data). This pilot study indicated the innocuity or even the potential benefit of a progesterone treatment to improve fertility in cyclical pubertal does. Since in vitro-manipulated embryos have a lower viability than normal, being smaller in size at early embryonic stages (Bertolini et al., 2002; Martin et al., 2007), it is possible that the rescue of some less viable embryos may have occurred (Bertolini et al., 2002), resulting in higher pregnancy rates than that reported in the literature for cloned goat embryos (Chavatte-Palmer et al., 2013).

Despite the low overall efficiency of cloning by SCNT observed in this study, especially regarding birth rates, we report the birth of a cloned goat female in August 2012, from control non-transgenic cells, using the micromanipulation of in vitro-matured oocytes with zona pellucida, membrane fusion, conventional activation, and transfer at the 1-cell stage embryo to the oviduct of a recipient female receiving progesterone supplementation throughout pregnancy. The important information generated in this study may serve as a basis for subsequent studies, which may contribute in the future to a greater efficiency in the production of transgenic cloned animal models in arid regions of the world, and to models that can assist in improving the quality of life of the population, such as milk-containing human lysozyme. In this sense, studies that take into account the physiology, nutrition, health, and reproductive aspects, among others (Bertolini, 2009), are required to uncover factors associated with lower reproductive performance in goat herds in the Brazilian Semi-Arid region.

\section{Acknowledgments}

This study was supported by the RECODISA project $(0460 / 08)$, sponsored by FINEP/MCT/Brazil, and by the FIT/2010 project, sponsored by FUNCAP/CE/Brazil. CF received a $\mathrm{CNPq}$ doctoral fellowship (142011/2010-0) during the experiments. The authors would like to thank J.L. Almeida, A.K.F. Costa, A.P. Almeida, K.C.S. Tavares, L.T. Martins, S. Gaudencio Neto, N. Mohamad-Fauzi, V.H.V. Rodrigues, and students, interns, and volunteers for technical assistance in parts of the study.

\section{References}

Akshey YS, MalakarD, De AK, Jena MK, Garg S, Dutta R, Pawar SK, Mukesh M. 2010. Hand-made cloned goat (Capra hircus) embryos - a comparison of different donor cells and culture systems. Cell Reprogram, 12:581-588.

American Academy of Pediatrics. Work Group on Breastfeeding. 1997. Breastfeeding and the use of human milk. Pediatrics, 100:1035-1039.

An L, Yuan Y, Yu B, Yang T, Cheng Y. 2012. 
[Cloning goat producing human lactoferrin with genetically modified donor cells selected by single or dual markers]. Sheng Wu Gong Cheng Xue Bao, 28:1482-1491.

Apimeteetumrong M, Thuangsanthia A, Leingcharoen N. 2004. The effect of activation protocols on the development of cloned goat embryos. $J$ Vet Med Sci, 66:1529-1534.

Baguisi A, Behboodi E, Melican DT, Pollock JS, Destrempes MM, Cammuso C, Williams JL, Nims SD, Porter CA, Midura P, Palacios MJ, Ayres SL, Denniston RS, Hayes ML, Ziomek CA, Meade HM, Godke RA, Gavin WG, Overstrom EW, Echelard Y. 1999. Production of goats by somatic cell nuclear transfer. Nat Biotechnol, 17:456-461.

Bai DP, Yang MM, Qu L, Chen YL. 2017. Generation of a transgenic cashmere goat using the piggyBac transposition system. Theriogenology, 93:1-6. doi: 10.1016/j.theriogenology.2017.01.036.

Baldassarre H, Wang B, Keefer CL, Lazaris A, Karatzas CN. 2004. State of the art in the production of transgenic goats. Reprod Fertil Dev, 16, 465-470.

Behboodi E, Memili E, Melican DT, Destrempes MM, Overton SA, Williams JL, Flanagan PA, Butler RE, Liem H, Chen LH, Meade HM, Gavin WG, Echelard Y. 2004. Viable transgenic goats derived from skin cells. Transgenic Res, 13:215-224.

Bertolini M, Beam SW, Shim H, Bertolini LR, Moyer AL, Famula TR, Anderson GB. 2002. Growth, development, and gene expression by in vivo- and in vitro-produced day 7 and 16 bovine embryos. Mol Reprod Dev, 63:318-328.

Bertolini M. 2009. Advances in reproductive technologies in cattle: from artificial insemination to cloning. Rev Fac Med Vet Zootec, 56:184-194.

Boccolini CS, Boccolini PMM, Carvalho ML, Couto OMI. 2012. Padrões de aleitamento materno exclusivo e internação por diarreia entre 1999 e 2008 em capitais brasileiras. Cienc Saude Colet, 17:1857-1863.

Booth PJ, Tan SJ, Reipurth R, Holm P, Callesen H. 2001. Simplification of bovine somatic cell nuclear transfer by application of a zona-free manipulation technique. Cloning Stem Cells, 3:139-150.

Carneiro GF. 2008. Biotécnicas da reprodução assistida em pequenos ruminantes. Tecnol Cienc Agropec, 2:23-28.

Cecconi S, Mauro A, Capacchietti G, Berardinelli P, Bernabò N, Di Vincenzo AR, Mattioli M, Barboni B 2007. Meiotic maturation of incompetent prepubertal sheep oocytes is induced by paracrine factor(s) released by gonadotropin-stimulated oocyte-cumulus cell complexes and involves mitogen-activated protein kinase activation. Endocrinology, 149:100-107.

Chavatte-Palmer P, Lee $\mathbf{R}$, Bertolini $\mathbf{M}$, Jammes $\mathbf{H}$, Schmidt M, Callesen H. 2013. Pregnancy and neonatal care of SCNT animals. In: Cibelli J, Wilmut IS, Jaenisch R, Gurdon J, Lanza R, West M, Campbell KHS (Ed.). Principles of Cloning. 2nd ed. London: Academic Press. pp. 107-126.

Chaves RM, Aguiar FC, Santos JE, Almeida FJM, Lima PF, Oliveira MAL. 2010. Efeito do diâmetro folicular sobre a qualidade dos oócitos obtidos de ovários de ovelhas (Ovis aries) e cabras (Capra hircus). Cienc Anim Bras, 11:683-688.

Chaves RM, Bezerra FQG, Lima PF, Rabelo MC, Lopes FP, Oliveira MAO. 2011. Maturação Nuclear in vitro e morte celular por apoptose em oócitos de caprinos nos períodos seco e chuvoso. Cienc Anim Bras, 12:593-601.

Chen DY, Jiang MX, Zhao ZJ, Wang HL, Sun Q, Zhang LS, Li RC, Cao H, Zhang Q, Ma DL. 2007. Cloning of Asian Yellow Goat (C. hircus) by somatic cell nuclear transfer: telophase enucleation combined with whole cell intracytoplasmic injection. Mol Reprod Dev, 74;28-34

Chow BD, Reardon JL, Perry EO, Laforce-Nesbitt SS, Tucker R, Bliss JM. 2016. Host defense proteins in breast milk and neonatal yeast colonization. J Hum Lact, 32:168-173.

Colato C, Albornoz M, Mellano ML, Mellano PH, Mellano JI, Meltsas A, Mellano MA, Mellano JC, Bordignon V, Baldassarre H. 2011. Production of cloned boer goats and dorper sheep in Argentina. Reprod Fertil Dev Suppl, 23:123. (abstract).

Cooper CA, Maga EA, Murray JD. 2015. Production of human lactoferrin and lysozyme in the milk of transgenic dairy animals: past, present, and future. Transgenic Res, 24:605-614.

Dominko T, Ramalho-Santos J, Chan A, Moreno RD, Luetjens CM, Simerly C, Hewitson L, Takahashi D, Martinovich C, White JM, Schatten G. 1999. Optimization strategies for production of mammalian embryos by nuclear transfer. Cloning, 1:143-152.

Dutta R, Malakar D, Khate K, Sahu S, Akshey Y, Mukesh M. 2011. A comparative study on efficiency of adult fibroblast, putative embryonic stem cell and lymphocyte as donor cells for production of handmade cloned embryos in goat and characterization of putative ntES cells obtained from these embryos. Theriogenology, 76:851-863.

Edwards JL, Hansen PJ. 1996. Elevated temperature increases heat shock protein 70 synthesis in bovine twocell embryos and compromises function of maturing oocytes. Biol Reprod, 55:340-346.

Fatehi AN, Roelen BAJ, Colenbrander B, Schoevers EJ, Gadella BM, Bevers MM, Van Den Hurk R. 2005. Presence of cumulus cells during in vitro fertilization protects the bovine oocyte against oxidative stress and improves first cleavage but does not affect further development. Zygote, 13:177-185.

Feltrin C, Forell F, Santos LC, Rodrigues JL. 2006. In vitro bovine embryo development after nuclear transfer by HMC using a modified WOW culture system. Reprod Fertil Dev Suppl, 18:126. (abstract).

Feng X, Cao S, Wang H, Meng C, Li J, Jiang J, Qian Y, Su L, He Q, Zhang Q. 2015. Production of transgenic dairy goat expressing human $\alpha$-lactalbumin by somatic cell nuclear transfer. Transgenic Res, 24:7385

Fissore RA, Long CR, Duncan RP, Robl JM. 1999. Initiation and organization of events during the first cell cycle in mammals: applications in cloning. Cloning, $1: 88-100$. 
Folch J, Cocero MJ, Chesne'c P, Alabart JL, Domınguez V, Cognie'd V, Roche A, FernandezArias A, Martıa I, Sanchez P, Echegoyen E, Beckers JF, Sanchez AB, Vignon X. 2009. First birth of an animal from an extinct subspecies. Theriogenology, 71:1026-1034.

Gavin W, Chen L, Schofield M, Masiello N, Meade H, Echelard Y. 2013. Transgenic cloned goats and the production of recombinant therapeutic proteins. In: Cibelli J, Wilmut IS, Jaenisch R, Gurdon J, Lanza R, West M, Campbell KHS. (Ed.). Principles of Cloning. London: Academic Press. pp. 329-342.

Gerger RP, Ribeiro ES, Forell F, Bertolini LR, Rodrigues JL, Ambrósio CE, Miglino MA, Mezzalira A, Bertolini M. 2010. In vitro development of cloned bovine embryos produced by handmade cloning using somatic cells from distinct levels of cell culture confluence. Genet Mol Res, 9:295-302.

Guimarães FC. 2006. Situação atual e perspectivas da caprinocultura no Vale do São Francisco. In: Congresso Nordestino de Produção Animal, 6, 2006, Petrolina, PE. Petrolina, PE: SNPA. 14 pp. CD-ROM.

Hassiotou F, Geddes DT. 2015. Immune cell-mediated protection of the mammary gland and the infant during breastfeeding. Adv Nutr, 62:67-75.

Holm P, Booth PJ, Schmidt MH, Greve T, Callesen H. 1999. High bovine blastocyst development in a static in vitro production system using SOFaa medium supplemented with sodium citrate and myo-inositol with or without serum-proteins. Theriogenology, 52:683-700. Hosseini SM, Hajianm M, Forouzanfar M, Ostadhosseini S, Moulavi F, Ghanaei HR, Gourbai H, Shahverdi AH, Vosough AD, Nasr-Esfahani MH. 2015. Chemically assisted somatic cell nuclear transfer without micromanipulator in the goat: effects of demecolcine, cytochalasin-B, and MG-132 on the efficiency of a manual method of oocyte enucleation using a pulled Pasteur pipette. Anim Reprod Sci, 158:1118.

Jordan ER. 2003. Effects of heat stress on reproduction. J Dairy Sci, 86:104-114.

Keefer CL, Baldassarre $H$, Keyston $R$, Wang B, Bhatia B, Bilodeau AS, Zhou JF, Leduc M, Dwney BR, Lazaris A, Karatzas CN. 2001. Generation of dwarf goat (Capra hircus) clones following nuclear transfer with transfected and nontransfected fetal fibroblasts and in vitro-matured oocytes. Biol Reprod, 64:849-856.

Keefer CL, Keyston R, Lazaris A, Bhatia B, Begin I, Bilodeau AS, Zhou FJ, Kafidi N, Wang B, Baldassarre H, Karatzas CN. 2002. Production of cloned goats after nuclear transfer using adult somatic cells. Biol Reprod, 66:199-203.

Kelly JM, Kleeman DO, Rudiger SR, Walker SK. 2007. Effects of grade of oocyte-cummulus complex and the interactions between grades on the blastocysts in the cow, ewe and lamb. Reprod Domest Anim, 42:577582.

Król JZ, Litwińczuk A, Brodziak J, Barłowska JZ. 2010. Lactoferrin, lysozyme and immunoglobulin $G$ content in milk of four breeds of cows managed under intensive production system. Pol J Vet Sci, 13:357-361.
Lan GC, Chang ZL, Luo MJ, Jiang YL, Han D, Wu YG. 2006. Production of cloned goats by nuclear transfer of cumulus cells and long-term cultured fetal fibroblast cells into abattoir-derived oocytes. Mol Reprod Dev, 73:834-840.

Lechner BE, Vohr BR. 2017. Neurodevelopmental outcomes of preterm infants fed human milk: a systematic review. Clin Perinatol, 44:69-83.

Leibfried L, First NL. 1979. Characterization of bovine follicular oocytes and their ability to mature in vitro. J Anim Sci, 48:76-86.

Levy J. 1998. Immunonutrition: The pediatric experience. Nutrition, 14:641-647.

Liu J, Li LL, Du S, Bai XY, Zhang HD, Tang S, Zhao MT, Ma BH, Quan FS, Zhao XE, Zhang Y. 2011. Effects of interval between fusion and activation, cytochalasin B treatment, and number of transferred embryos, on cloning efficiency in goats. Theriogenology, 76:1076-1083.

Lönnerdal B. 2003. Nutritional and physiologic significance of human milk proteins. Am J Clin Nutr, $77: 1537-1543$

Lönnerdal B. 2016. Human milk: bioactive proteins/peptides and functional properties. Nestle Nutr Inst Workshop Ser, 86:97-107.

Maga EA, Murray JD. 1995. Mammary gland expression of transgenes and the potential for altering the properties of milk. Biotechnology, 13:1452-1457.

Maga EA, Cullor JS, Smith W, Anderson GB, Murray JD. 2006a. Human lysozyme expressed in the mammary gland of transgenic dairy goats can inhibit the growth of bacteria that cause mastitis and the coldspoilage of milk. Foodborne Pathog Dis, 3:384-392.

Maga EA, Walker RL, Anderson GB, Murray JD. 2006b. Consumption of milk from transgenic goats expressing human lysozyme in the mammary gland results in the modulation of intestinal microflora. Transgenic Res, 15:515-519.

Martin L, Besch-Williford C, Lai L, Cheong HT, Im GS, Park KW, Murphy C, Hao Y, Ellersieck MR, Keisler DH, Schatten H, Green JA, Prather RS. 2007. Morphologic and histologic comparisons between in vivo and nuclear transfer derived porcine embryos. Mol Reprod Dev, 74:952-960.

Martins LT, Gaudêncio Neto $S$, Tavares KC, Calderón CE, Aguiar LH, Lazzarotto CR, Ongaratto FL, Rodrigues VH, Carneiro IS, Rossetto R, Almeida AP, Fernandes CC, Rondina D, Dias AC, Chies JM, Polejaeva IA, Rodrigues JL, Forell F, Bertolini LR, Bertolini M. 2016. Developmental outcome and related abnormalities in goats: comparison between somatic cell nuclear transfer- and in vivoderived concepti during pregnancy through term. Cell Reprogram, 18:264-279.

Melican D, Gavin W. 2008. Repeat superovulation, non-surgical embryo recovery, and surgical embryo transfer in transgenic dairy goats. Theriogenology, 69:197-203.

Meng Q, Hall J, Rutigliano H, Zhou X, Sessions BR, Stott R, Panter K, Davies CJ, Ranjan R, Dosdall D, MacLeod R, Marrouche N, White KL, Wang Z, Polejaeva IA. 2012. Generation of cloned transgenic 
goats with cardiac specific overexpression of transforming growth factor $\beta 1$. Reprod Fertil Dev Suppl, 25:162-163.

Mohapatra SK, Sandhu A, Neerukattu VS, Singh KP, Selokar NL, Singla SK, Chauhan MS, Manik RS, Palta P. 2015. Buffalo embryos produced by handmade cloning from oocytes selected using brilliant cresyl blue staining have better developmental competence and quality and are closer to embryos produced by in vitro fertilization in terms of their epigenetic status and gene expression pattern. Cell Reprogram, 17:141-150.

Monaco E, Lima AS, Bionaz M, Maki A, Wilson S, Hurley WL, Wheeler MB. 2009. Morphological and transcriptomic comparison of adipose and bone marrow derived porcine stem cells. Open Tissue Eng Regen Med $J, 2: 20-33$.

Mountzouris KC, McCartney AL, Gibson GR. 2002. Intestinal microflora of human infants and current trends for its nutritional modulation. Br J Nutr, 87:405420.

Nasr-Esfahani MH, Hosseini SM, Hajian M, Forouzanfar M, Ostadhosseini S, Abedi P, Khazaie Y, Dormiani K, Ghaedi K, Forozanfar M, Gourabi H, Shahverdi AH, Vosough AD, Vojgani H. 2011. Development of an optimized zona-free method of somatic cell nuclear transfer in the goat. Cell Reprogram, 13:157-170.

Oback B, Wiersema AT, Gaynor P, Laible G, Tucker FC, Oliver JE, Miller AL, Troskie HE, Wilson KL, Forsyth JT, Berg MC, Cockrem K, McMillan V, Tervit HR, Wells DN. 2003. Cloned cattle derived from a novel zona-free embryo reconstruction system. Cloning, 5:3-12.

Oddy WH. 2017. Breastfeeding, childhood asthma, and allergic disease. Ann Nutr Metab,70:26-36.

Ohkoshi K, Takahashi S, Koyama S, Akagi S, Adachi N, Furusawa TD, Fujimoto J, Takeda K, Kubo M, Izaike Y, Tokunaga T. 2003. In vitro oocyte culture and somatic cell nuclear transfer used to produce a live-born cloned goat. Cloning Stem Cells, 5:109-115.

Pereira AF, Feltrin C, Almeida KC, Carneiro IS, Avelarm SRG, Neto AS, Alcântara SFC, Melo CHS, Moura RR, Teixeira DIA, Bertolini LR, Freitas VJF, Bertolini M. 2013. Analysis of factors contributing to the efficiency of the in vitro production of transgenic goat embryos (Capra hircus) by handmade cloning (HMC). Small Rumin Res, 109:163-172.

Peura TT, Lewis IM, Trounson AO. 1998. The effect of recipient oocyte volume on nuclear transfer in cattle. Mol Reprod Dev, 50:185-191.

Peura TT. 2003. Improved in vitro development rates of sheep somatic cell nuclear transfer embryos by using a reverse-order zona-free cloning methods. Cloning Stem Cells, 5:13-24.

Reggio BC, James AN, Green HL, Gavin W, Behboodi E, Echelard Y, Godke RA. 2001. Cloned transgenic offspring resulting from somatic cell nuclear transfer in the goat: oocytes derived from both folliclestimulating hormone-stimulated and nonstimulated abattoir-derived ovaries. Biol Reprod, 65:1528-1533.

Ribeiro ES, Gerger RPC, Ohlweiler LU, Ortigari JI,
Mezzalira JC, Forell F, Bertolini LR, Rodrigues JL, Ambrósio CR, Miglino MA, Mezzalira A, Bertolini M. 2009. Developmental potential of bovine hand-made clone embryos reconstructed by aggregation or fusion with distinct cytoplasmic volumes. Cloning Stem Cells, 11:377-386.

Roth Z, Hansen PJ. 2004. Sphingosine 1-phosphate protects bovine oocytes from heat shock during maturation. Biol Reprod, 71:2072-2078.

Stenfors LE, Bye HM, Räisänen S. 2002. Immunocytochemical localization of lysozyme and lactoferrin attached to surface bacteria of the palatine tonsils during infectious mononucleosis. J Laryngol Otol, 116:264-268.

Tang S, Liu J, Du S, Li LL, Zheng CY, Zhao MT, Wang YS, Zhang Y. 2011. Optimization of embryo culture conditions in the production of cloned goat embryos, following somatic cell nuclear transfer. Small Rumin Res, 96:64-69.

Vajta G, Peura TT, Holm P, Paldi A, Greve T, Trounson AO, Callesen H. 2000. New method for culture of zona-included or zona-free embryos: the well of the well (WOW) system. Mol Reprod Dev, 55:256264.

Verduci E, Banderali G, Barberi S, Radaelli G, Lops A, Betti F, Riva E, Giovannini M. 2014. Epigenetic effects of human breast milk. Nutrients, 6:1711-1724.

Victora C, Horta BL, Mola CL, Quevedo L, Pinheiro RT, Gigante DP, Gonçalves H, Barros FC. 2015. Association between breastfeeding and intelligence, educational attainment, and income at 30 years of age: a prospective birth cohort study from Brazil. Lancet Global Health, 3:e199-205.

Vinoles C, Forsberg M, Banchero G, Rubianes E. 2002. Ovarian follicular dynamics and endocrine profiles in Polwarth ewes with high and low body condition. J Anim Sci, 74:539-545.

Wells DN, Berg MC, Cole SAE, Cullum AA, Oback FC, Oliver JE, Gavin WG, Laible G. 2011. Effect of activation method on in vivo development following somatic cell nuclear transfer in goats. Reprod Fertil Dev Suppl, 24, 127-128.

Westhusin ME, Collas P, Marek D. 1996. Reducing the amount of cytoplasm available for early embryonic development decreases the quality but not the quantity of embryos produced by in vitro fertilization and nuclear transplantation. Theriogenology, 46:243-252.

Yang M, Hall J, Fan Z, Regouski M, Meng Q, Rutigliano HM, Stott R, Rood KA, Panter KE, Polejaeva IA. 2016a. Oocytes from small and large follicles exhibit similar development competence following goat cloning despite their differences in meiotic and cytoplasmic maturation. Theriogenology, 86:2302-2311.

Yang Z, Vajta G, Xu Y, Luan J, Lin M, Liu C, Tian J, Dou H, Li Y, Liu T, Zhang Y, Li L, Yang W, Bolund L, Yang H, Du Y. 2016b. Production of pigs by hand-made cloning using mesenchymal stem cells and fibroblasts. Cell Reprogram, 18:256-263.

Yuan YG, An L, Yu B, Song S, Zhou F, Zhang L, Gu Y, Yu M, Cheng Y. 2014. Expression of recombinant human alpha-lactalbumin in the milk of transgenic goats 
using a hybrid promoter/enhancer. J Anal Methods Chem, 2014:281031. doi: 10.1155/2014/281031.

Zhang L, Wan ZY, Wang D, Xu XS, Pang L, Meng LH, Wang ZFW. 2010. Production of dairy goat embryos, by nuclear transfer, transgenic for human acid $\beta$ - glucosidase. Theriogenology, 73:681-690.

Zhang YL, Zhang GM, Wan YJ, Jia RX, Li PZ, Han L, Wang F, Huang MR. 2015. Identification of transgenic cloned dairy goats harboring human lactoferrin and methylation status of the imprinted gene IGF2R in their lungs. Genet Mol Res, 14:11099-11109

Zhou ZR, Zhong BS, Jia RX, Wan YJ, Zhang YL, Fan YX, Wang LZ, You JH, Wang ZY, Wang F. 2013. Production of myostatin-targeted goat by nuclear transfer from cultured adult somatic cells. Theriogenology, 79:225-233. 